\title{
Analysis of Factors for Palliative Care for Breast Cancer Patients in Java in 2020
}

\author{
Harnanik Nawangsari ${ }^{1, *}$, Liliek Pratiwi ${ }^{2}$, \\ ${ }^{1,2}$ Lecturer of STIKES Insan Cendekia Medika Jombang, Lecturer of the Faculty of Health Sciences, Muhammadiyah \\ University of Cirebon \\ *Corresponding author. Email: harnanik.nawangsari@gmail.com
}

\begin{abstract}
This study pays attention to breast cancer patients in Java Province in 2020 because it aims to analyze factors related to palliative care, especially for patients with cervical cancer. So, it is hoped that this research will be useful as a suggestion for breast cancer patient health services. In this study, using a cross sectional research method. Research data was taken from several sources such as cancer foundations and family planning associations. This study uses a measuring instrument in the form of instruments from secondary data and a PNPC (Problem and Needs of Palliative Care) questionnaire. The sampling method in this study was purposive sampling, with a total sample of 178 female patients with breast cancer. Patients with breast cancer $\geq 1$ year, age $\geq 20$ years, able to write and read, in a conscious and stable state, were the inclusion criteria for this study. From the results of the study, with multivariate analysis, linear regression, the monthly income was obtained (with a value of $\mathrm{t}=-2.90, \mathrm{p}$ value $=0.04$, $95 \% \mathrm{CI}=-3,789,-1,807)$, marital status $(\mathrm{t}=-2.10, \mathrm{p}$ value $=0.04,95 \% \mathrm{CI}=-3,111,-1,665)$, place of domicile $(\mathrm{t}=-5.10, \mathrm{p}$ value $=0.04,95 \% \mathrm{CI}=-4,211,-1,415)$, the patient also had difficulty accepting meaning or perceptions of death. Then breast cancer patients also felt difficult and confused to tell their complaints $(\mathrm{t}=-6.10$, $\mathrm{p}$ value $=0.04,95 \% \mathrm{CI}=-6.211,-1.667$, then the patient felt distressed and lacked knowledge about pain management $(\mathrm{t}=-5.33, \mathrm{p}$ value $=0.03$ 95\% CI $=-3.211,1.886$.From these factors the results are related to the palliative care of breast cancer patients in Java, Indonesia in 2020, with an $\mathrm{R}$ value of 0.109. This, nurses, doctors, families must increase their role proactively. The motivation of the patient's family must also be studied in the future because the patient's family is actively participating by participating in the training of doctors and nurses who perform health services to these patients. For other researchers, it can also improve further study so that palliative care of women with breast cancer can run smoothly both at home and in the hospital.
\end{abstract}

Keywords: patients with breast cancer, Java province, 2020

\section{INTRODUCTION}

Every year and from time to time, there are additional cases of breast cancer, based on WHO data, there are 1.38 million new cases and 458 thousand cases of breast cancer that end in death. Women can be attacked by breast cancer and cervical cancer with various trigger factors. The impact of the development of breast cancer cells, decreasing the quality of life for patients and their families. There were 58,256 cases out of a total of 348,809 cancer cases. If there are 17 people per 1000 population affected by breast cancer, of course the impact must be considered. The number of deaths increases because it can be various aspects, whether it is the decreased quality of life of the patient, family motivation or quality of care. There is a known etiology of breast cancer, some need further study. $10 \%$ of the etiology of breast cancer, due to genetic consequences of the parents. The rest is in the range of $90 \%$ usually suddenly gets Covid19.

Excess of the hormone estrogen affects the growth of breast cancer cells in patients. In addition, individual factors are also related, such as how long the use of hormonal contraceptives has been and factors are not breastfeeding and have never been pregnant. Previously and recently, from dietary factors, such as junk food in the long term and co-factors, can cause breast cancer. From the 2018 RISKESDAS data, cancer and tumors increased from 2013. Indonesia as a state in Southeast Asia is a country with 8th and 23rd rank in Asia, as a country with a number of cancer cases. Breast cancer is 42.1 per 100,000 population and is a concern of the public and medical personnel.

The cure rate for breast cancer patients varies depending on the severity and whether there are comorbidities. Research on the motivation, knowledge, attitudes of breast cancer patients has been done a lot, but novelty, but not yet studied the extent to which palliative care is carried out and its factors. Patients need parnert in maintaining their health. In some consumer accounts the patient's family is here.

\section{METHOD}

PNPC-sv consists of 33 question items related to problems and in reducing bias in this study, the number of samples in this study was taken 178 so that it could represent women with breast cancer in Java in 2020. The instrument in this study, namely the PNPC is a self- 
assessment. with seven domains, namely daily activities, physical symptoms, autonomy, social issues, psychological issues, spiritual issues and financial issues, the need for palliative care. Each item will be asked about the problem and from the perceived problem whether they need help from health workers with the answer choices are (yes, many / no). PNPC has a significant correlation with the dimensions of quality of life developed by EORTC QLQC30 (European Organization for Research and Treatment of Cancer Quality of Life Questionnaire-Core 30) with p value $=0.01$. PNPC also has good internal consistency Alpha value of $0.70-0.86$. PNPC also has good internal consistency.

\section{RESULT}

Based on the results of multivariate analysis with linear regression, it was found that monthly income $(\mathrm{t}=-2.90, \mathrm{p}$ value $=0.04,95 \% \mathrm{CI}=-3.789-$ - 1.807), marital status $(\mathrm{t}=$ $-2.10, p$ value $=0.04,95 \% \mathrm{CI}=-3,111--1,665)$, place of residence $(\mathrm{t}=-5.10, \mathrm{p}$ value $=0.04,95 \% \mathrm{CI}=-4,211-$ $1,415)$, difficulty perceiving the meaning of death $(t=-6.10$, $\mathrm{p}$ value $=0.07,95 \% \mathrm{CI}=-9,211--1,110)$, difficulty finding someone to tell stories or talk to $(\mathrm{t}=-6.10, \mathrm{p}$ value $=0.04$, $95 \% \mathrm{CI}=-6,211-\mathrm{1}, 677)$ difficulty in pain management $(\mathrm{t}$ $=-5.33, \mathrm{p}$ value $=0.03,95 \% \mathrm{CI}=-3.211-1.886)$ associated with palliative care for women with breast cancer in Indonesia in 2020, the R value is 0.109 In this study, it was found that the overall needs of cancer patients were in the upper middle class. From the results of the study, with multivariate analysis, linear regression, the monthly income was obtained (with a value of $\mathrm{t}=-2.90, \mathrm{p}$ value $=0.04,95 \%$ $\mathrm{CI}=-3,789,-1,807)$, marital status $(\mathrm{t}=-2.10, \mathrm{p}$ value $=0.04$, $95 \% \mathrm{CI}=-3,111,-1,665)$, place of domicile $(\mathrm{t}=-5.10, \mathrm{p}$ value $=0.04,95 \% \mathrm{CI}=-4,211,-1,415)$, the patient also had difficulty accepting meaning or perceptions of death. Then breast cancer patients also felt difficult and confused to tell their complaints $(\mathrm{t}=-6.10$, $\mathrm{p}$ value $=0.04,95 \% \mathrm{CI}=-6.211$, -1.667, then the patient felt distressed and lacked knowledge about pain management $(\mathrm{t}=-5.33$, $\mathrm{p}$ value $=$ $0.0395 \% \mathrm{CI}=-3.211,1.886$. From these factors the results are related to the palliative care of breast cancer patients in Java, Indonesia in 2020, with an R value of 0.109., 2015 that breast cancer patients hope that health workers who care for them can honestly say their condition and follow up their needs that have not been met. dimensions, as well as patientoriented care (Alikhani, 2019) In De Silva M's (2010) study, women who previously had a history of breastfeeding were healthier and less prone to breast cancer. From the research results, it was also stated that the use of health care facilities also affects the palliative needs of breast cancer patients. Society and community can play a more dominant role in hospital services for breast cancer patients. So, public awareness about the importance of palliative care must be raised again.

\section{CONCLUSION}

From the results of this study, it is better if the questionnaire regarding palliative care can be socialized to the hospital.
So, the hospital can improve the quality of health services. So, the advice for health service providers is not only medical personnel, but also families and communities in the form of comprehensive palliative service motivation.

\section{ACKNOWLEDGMENT}

The researchers would like to thank all those who have helped the course of this research until the research was published.

\section{REFERENCES}

[1] Anindita Mukherjee, Koustav Mazumder, Sushmita Ghoshal. Impact of different sociodemographic factors on mental health status of female cancer patients receiving chemotherapy for recurrent disease. 2018. 24 (4). (426430). Indian Journal of Palliative Care.

[2] Beasley JM, Kwan ML, Chen WY, et al. Meeting the physical activity guidelines and survival after breast cancer: findings from the after breast cancer pooling project. Breast Cancer Res Treat. 2012; 131: 637- 643.

[3] Bradshaw PT, Ibrahim JG, Khankari N, et al. Postdiagnosis physical activity and survival after breast cancer diagnosis: The Long Island Breast Cancer Study. Breast Cancer Res Treat. 2014; 145: 735- 742.

[4] Loprinzi PD, Cardinal BJ, Winters-Stone K, et al. Physical activity and the risk of breast cancer recurrence: a literature review. Oncol Nurs Forum. 2012; 39: 269- 274.

[5] Darby SC, Ewertz M, McGale P, Bennet AM, BlomGoldman U, Bronnum D, et al. Risk of ischemic heart disease in women after radiotherapy for breast cancer. New Engl J Med. 2013;368(11):987e98. http://dx.doi.org/10.1056/NEJMoa1209825

[6] World Health Organization. Breast cancer: prevention and control [cited 2012 June 3]. Available from: http://www.who.int/cancer/detection/breastcancer/ en/index.html

[7] Morrow M, Burstein HJ, and Harris JR. Malignant tumors of the breast. DeVita VT Jr, Lawrence TS, \& Rosenberg SA. (2015). Cancer: Principles and Practice of Oncology. (10th Edition). Philadelphia: Wolters Kluwer Health/Lippincott Williams \& Wilkins. 79: 1117-1156

[8] National Toxicology Program. (2016). 14th Report on Carcinogens. Department of Health and Human Services. Retrieved from: http://ntp.niehs.nih.gov/pubhealth/roc/index$1 . h$ tml.

[9] Wentlandt K, Krzyzanowska MK, Swami N, Rodin GM, Le LW, Zimmermann C. Refer- ral practices of oncologists to specialized palliative care. J Clin Oncol 2012;30: 4380-6.

[10] Hui D, Kim YJ, Park JC, Zhang Y, Strasser F, Cherny $\mathrm{N}$, et al. Integration of oncology and palliative care: a systematic review. Oncologist 2015;20:77-83.

[11] Oesman I. Dampak Kanker Payudara. In: Indah RSP, editor. Jakarta: PT Meta Publishing; 2012.

[12] De Silva M, Senarath U, Gunatilake M, Lokuhetty D. Prolonged breastfeeding reduces risk of breast cancer in Sri Lanka women. Cancer Epidemiol. 2010;34(3):267-73.

[13] Mahtab Alikhani, Soudabeh Vatankhah, Hasan Abolghasem Gorji, Hamid Ravaghi. A Comparison of Policy Analysis of Palliative Care for Cancer in UK, Malaysia, and South Africa. Int J Cancer Manag. 2019. 12(12):e94841 